\title{
ADAPTABILITAS KARIER GENERASI MILINEAL MENGHADAPI KEMAJUAN TEKHNOLOGI ERA INDUSTRI 4.0
}

\section{Rina Rindanah}

IAIN Syekh Nurjati Cirebon

\begin{tabular}{|c|c|}
\hline Informasi Artikel & ABSTRAK \\
\hline Histori Artikel: & Penelitian ini bertujuan untuk melihat adaptabilitas karier generasi \\
\hline Diterima 18 Agustus 2020 & milineal menghadapi kemajuan teknologi Era Industri 4.0. \\
\hline Revisi 10 September 2020 & Penelitian ini melibatkan 102 orang generasi milineal yang \\
\hline Disetujui 23 November 2020 & $\begin{array}{l}\text { statusnya masih sebagai mahasiswa di IAIN Syekh Nurjati Cirebon. } \\
\text { Teknik sampling yang digunakan adalah cluster random sampling. }\end{array}$ \\
\hline \multirow{10}{*}{$\begin{array}{l}\text { Penulis Korespondensi: } \\
\text { Rina Rindanah, } \\
\text { Email: } \\
\text { rinarindanah73@gmail.com }\end{array}$} & Pengambilan data dilakukan dengan menggunakan skala \\
\hline & adaptabilitas karier. Skala adaptabilitas karier diadaptasi dari Career \\
\hline & Adapt-Abilities Scale (CAAS) yang dibuat oleh Savickas, kemudian \\
\hline & $\begin{array}{l}\text { diperbaharui oleh Einarsdöttir et al. dengan nama Icelandic scales } \\
\text { dengan cara menambahkan dua dimensi adaptabilitas karier yaitu }\end{array}$ \\
\hline & $\begin{array}{l}\text { kerjasama dan kontribusi. Hasil penelitian menunjukkan } \\
\text { adaptabilitas karier pada generasi milineal dalam penelitian ini } \\
\text { berada pada kategori tinggi dengan rata-rata 94.18. Implikasi pada }\end{array}$ \\
\hline & kemajuan teknologi era industri 4.0 , generasi milineal memiliki \\
\hline & kesiapan untuk beradaptasi dalam kondisi apapun yang menjadi \\
\hline & $\begin{array}{l}\text { konsekuensi logis dari kemajuan di era industri } 4.0 \text {. Hasil analisa } \\
\text { memperlihatkan adanya perbedaan signifikan dalam adaptabilitas }\end{array}$ \\
\hline & $\begin{array}{l}\text { karier remaja yang disebabkan oleh jenis kelamin laki-laki dan } \\
\text { perempuan. }\end{array}$ \\
\hline & $\begin{array}{l}\text { Kata kunci: Adaptabilitas karier; generasi milineal; era industri } \\
4.0\end{array}$ \\
\hline
\end{tabular}

\section{PENDAHULUAN}

Perkembangan dunia abad 21 sangat dinamis yang ditandai dengan lahirnya era industri 4.0. Era industri 4.0 menurut Schlechtendahl et al. (2015) menekankan kepada unsur kecepatan dari ketersediaan informasi, yaitu sebuah lingkungan industri di mana seluruh entitasnya selalu terhubung dan mampu berbagi informasi satu dengan yang lain. Pengertian yang lebih teknis disampaikan oleh Kagermann et al. (2013) bahwa Industri 4.0 adalah integrasi dari Cyber Physical System (CPS) dan Internet of Things and Services (IoT dan IoS) ke dalam proses industri meliputi manufaktur dan logistik serta proses lainnya. CPS adalah teknologi untuk menggabungkan antara dunia nyata dengan dunia 
maya. Penggabungan ini dapat terwujud melalui integrasi antara proses fisik dan komputasi (teknologi embedded computers dan jaringan) secara close loop (Lee, 2008).

Tantangan yang dihadapi pada era ini sangat kompleks, sehingga menjadikan setiap individu perlu mempersiapkan diri dengan baik. Salah satu tantangan yang dihadapi pada era ini adalah ketidakpastian global (global uncertainty). Pada era ketidakpastian, individu perlu memiliki kemampuan dan kepekaan dalam menghadapi tantangan menjadi peluang. Secara sederhana tantangan revolusi industry 4.0 mencakup: (1) kesiapan industri; (2) tenaga kerja terpercaya; (3) kemudahan pengaturan sosial budaya; dan (4) diversifikasi dan penciptaan lapangan kerja. Sedangkan peluangnya adalah; (1) inovasi ekosistem; (2) basis industri yang kompetitif; (3) investasi pada teknologi; dan (4) integrasi Usaha Kecil Menengah (UKM) dan kewirausahaan (Irianto, 2014).

Setiap individu yang ingin eksistensi dirinya tetap terjaga dalam kompetisi global harus menyiapkan mental, skill dan mempunyai keunggulan persaingan (competitive advantage). Jalan utama mempersiapkan skill yang paling mudah ditempuh adalah memiliki perilaku yang baik (behavioral attitude), menaikan kompetensi diri dan memiliki semangat literasi. Bekal persiapan diri tersebut dapat dilalui dengan jalur pendidikan (long life education) dan konsep diri melalui pengalaman bekerja sama lintas generasi (experince is the best teacher) (Suwardana, 2017).

Skill yang perlu dimiliki untuk menghadapi kondisi seperti itu dibutuhkan kemampuan menyesuaikan diri (beradaptasi) dengan perubahan. Kemampuan menyesuaikan diri perlu dilakukan dalam segala bidang kehidupan, seperti pendidikan, sosial, ekonomi hingga karier. Sebagai contoh, dalam pendidikan kemampuan beradaptasi perlu dimiliki oleh guru maupun siswa. Guru dengan kemampuan adaptasi akan menggunakan metode pembelajaran yang disesuaikan dengan karaktersitik anak didik, materi dan sarana prasarana yang tersedia. Dengan kemampuan adaptasi yang baik, maka akan tercipta pembelajaran berkualitas yang pada akhirnya akan melahirkan siswa kreatif, aktif dan inovatif.

Dalam bidang ekonomi kemampuan beradaptasi perlu dimiliki oleh pengusaha (enterpreuner) maupun pekerja (employer). Perkembangan teknologi menjadikan pengusaha memiliki peluang yang sama untuk berkompetisi dalam menciptakan pekerjaan yang kreatif sesuai tuntutan zaman. Dampak dari revolusi industri 4.0 juga memunculkan keuntungan bagi pengusaha, diantaranya: (1) dimudahkannya konsumen untuk mencukupi 
kebutuhan, (2) teknologi yang memudahkan dengan sistem digital, (3) melahirkan kompetisi positif berbasis inovasi, (4) mengurangi jumlah pengangguran dan (5) meningkatkan pertumbuhan ekonomi. Sementara bagi pekerja, kemampuan adaptasi dibutuhkan untuk menyesuaikan diri dengan perubahan pekerjaan. Individu yang bisa beradaptasi dalam pekerjaan, karier, atau profesi akan terjaga keberlangsungan karirnya (career sustainable), sehingga memperoleh ketenangan, peningkatan, pengembangan dan kebahagiaan karir.

Dari beberapa hal di atas dapat disimpulkan bahwa adaptabilitas mempunyai peranan penting dalam kehidupan. Individu yang bisa beradaptasi mempunyai peluang yang lebih besar untuk menyelesaikan persoalan dan memperoleh kebahagiaan, demikian sebaliknya ketidakmampuan beradaptasi akan menjadikannya tergerus perubahan zaman. Disamping itu, kemampuan beradaptasi akan menjadikan individu bisa menempatkan diri dalam segala bidang kehidupan yang ditandai dengan mudah menjalin relasi, mampu merespon perubahan dengan cepat, memiliki semangat untuk berkarya, semangat ingin tahu yang besar dan kemampuan mengambil keputusan dengan bijak. Kemampuan beradaptasi merupakan keterampilan dasar yang dibutuhkan dunia kerja saat ini. Dunia kerja membutuhkan orang-orang yang mampu merespon perkebangan zaman yang lebih baik, memiliki kompetensi dan kemauan yang keras untuk belajar dan berubah ke arah yang lebih baik.

Adaptabilitas karir didefinisikan sebagai kemampuan untuk beradaptasi dengan persyaratan pekerjaan dan kemampuan untuk berganti pekerjaan yang lebih sesuai dengan kebutuhan individu (Pratzner \& Ashley, 1984). Kesiapan seseorang dalam memilih kariernya dikenal dengan konsep adaptabilitas karier. Menurut Cossette \& Allison (dalam Gunawan, 2013) adaptabilitas karier dicetuskan tahun 1979 oleh Super dimana diartikan kesiapan seseorang dalam menghadapi perubahan situasi dan kerja. Savickas (dalam Gunawan, 2013) menyatakan bahwa adaptabilitas karier menggantikan konsep kematangan karier sebagai konstruk utama dalam perkembangan karier pada berbagai kelompok usia sepanjang rentang kehidupan seseorang. Savickas \& Porfeli (2012) menyatakan adaptabilitas karier merupakan kesiapan seseorang dalam mengatasi tugastugas yang telah diprediksi dan mampu berpartisipasi dalam peran pekerjaannya.

Adaptabilitas karier digunakan oleh individu untuk dapat memilih tindakan yang tepat dalam menghadapi perubahan dalam lingkungan kerja, transisi kerja maupun trauma 
terhadap kerja (Savickas, 1997). Kemampuan individu dalam beradaptasi dapat membantu individu dalam menghadapi tuntutan baru dalam dunia kerja maupun lingkungan kerja yang beragam. Career adaptability juga dapat membantu individu dalam merefleksikan tujuan utamanya dalam organisasi yang sekarang ditempatinya Parker dalam (Savickas, 1997). Dengan demikian adaptabilitas karier sangatlah penting bagi individu untuk kesuksesan kariernya. Kemampuan beradaptasi berkontribusi positif terhadap kesejahteraan secara keseluruhan dan lebih spesifik lagi kepuasan hidup, meningkatkan kepuasan akademik (Douglass \& Duffy, 2015), kepuasan kerja, dan kepuasan karier, faktor pelindung dan dapat memediasi hubungan antara ketidaknyamanan kerja, ketegangan kerja dan hasil kerja, berdampak positif terhadap tujuan karier dan perilaku. Adaptabilitas berarti kualitas untuk mampu berubah, tanpa kesulitan berarti untuk menyesuaikan diri dengan kondisi yang berubah atau kondisi yang baru (Savickas, 1997; Lent \& Brown, 2006).

Begitu pentingmya adaptabilitas bagi keberlangsungan kerja seseorang, mahasiswa yang menjadi bagian dari masyarakat diharapkan memiliki kesiapan untuk beradaptasi dengan lingkungan kerja dimana mereka pada saatnya akan bekerja. Berdasarkan beberapa kajian yang telah dipaparkan, penting bagi konselor di Perguruan Tinggi untuk mengetahui adaptabilitas karier mahasiswa. Konselor dengan pengetahuan yang baik mengenai adaptabilitas karier mahasiswa dan intervensinya diharapkan dapat memberikan pelayanan terbaik untuk konseli sehingga diharapkan mahasiswa dapat beradaaptasi dan memimiliki kesiapan memasuki dunia kerja dengan problematikanya.

Bagaimana adaptabilitas karier mahasiswa dan implikasinya di era industri 4.0, menjadi hal yang menarik untuk dilakukan penelitian. Kepentingannya adalah bagi mahasiswa yang sudah memiliki adaptabilitas tinggi diharapkan terus dipertahankan dan ditingkatkan dan bisa dilakukan treatmen terhadap mahasiswa yang tidak memiliki kesiapan dan beradaptasi dalam karier. Penelitian yang dilakukan bertujuan untuk mengetahui adaptabilitas karier mahasiswa dengan menggunakan instrumen adaptabilitas karier.

Adaptabilitas karier merupakan konsep baru yang diperkenalkan oleh Savickas, untuk menggantikan konsep kematangan karier. Konsep adaptabilitas karier memiliki empat dimensi yang mengindentifikasi adanya pengalaman negatif dari orang-orang muda dalam pemilihan karier (Gunawan, 2013). Savickas berpendapat, di dalam dunia yang 
penuh perubahan yang terjadi di dalam dunia kerja dan lingkungan, maka konsep adaptabilitas karier bermanfaat untuk diteliti lebih lanjut pada remaja (Savickas, 2012), terutama pada remaja Indonesia. Kemampuan dalam beradaptasi dengan perubahan yang diukur dengan adaptabilitas karier sangat mambantu dalam mencapai kesuksesan. Adaptabilitas karier merupakan bagian dari Teori konstruksi karier dari Savickas (dalam Lent \& Brown, 2006) yang menjelaskan tentang proses seseorang melalui masa perkembangan karier, cara kerja mereka, dan tujuan karier mereka.

Hasil penelitian para peneliti bahwa adaptabilitas karier sangat berpengaruh terhadap kekuatan self-regulatory yang memiliki kemampuan untuk berubah seiring waktu dalam menanggapi orang, lingkungan dan interaksi antara keduanya (Savickas \& Porfeli, 2011) membangun psikologis yang menunjukkan kesiapan individu dan sumber daya untuk mengatasi tugas-tugas pekerjaan, transisi pekerjaan dan trauma pribadi, membentuk diri ekstensi ke lingkungan sosial (Savickas, 2013). Creed et al. (2009) dalam Yousefi, Z et al. (2011), memiliki pengalaman pendidikan jauh lebih terstruktur, dapat memantau dan menyelesaikan masalah arah karier dengan baik dan berkembang lebih dewasa. Selain itu, adaptasi karier memiliki hubungan yang kuat dengan spiritual dan agama karena motivasi intrinsik cenderung lebih percaya diri dalam kemampuan mereka untuk membuat keputusan karier dan terbuka untuk menjelajahi berbagai pilihan karier.

Adaptabilitas karier seseorang dapat dibedakan dari beberapa hal. Satu diantaranya dapat dibedakan dari jenis kelamian; laki-laki dan perempuan Jenis kelamin merupakan faktor internal dalam kesiapan seseorang dalam mengatasi tugas-tugasnya terutama pada usia remaja. Menurut MacNair dan Brown (dalam Seligman, 1994), kematangan karier remaja perempuan lebih tinggi daripada kematangan karier remaja laki-laki seusianya. Hal tersebut dikarenakan cara menjalin hubungan dengan orang lain remaja perempuan cenderung berinteraksi langsung, sehingga akan jauh lebih mudah untuk mencari dan mendapatkan informasi tentang karier. Pada remaja laki-laki cenderung berfokus pada dirinya sendiri untuk menjadi lebih mandiri.

Penelitian tentang adaptabilitas karier terus dilakukan dengan instrumen yang selalu dikembangkan. Beberapa instumen yang telah dikembangkan untuk meneliti adaptabilitas karier individu seperti Career Isues Survey (CIS), Career Adapt-Abilities ScaleInternational Form (CAAS), Vocational Identity Status Assesment (VISA), Career Development Inventory (CDV), namun masih menggunakan empat dimensi (indikator) 
Savickas (2013) mengidentifikasi empat dimensi dari adaptabilitas karier, (a) Kepedulian tentang masa depan (concern about the future), (b) Pengendalian atas hidup mereka (control over their lives), (c) Rasa ingin tahu tentang karier pekerjaan (curiosity about occupational careers), dan (d) Percaya diri untuk membangun masa depan dan berurusan dengan karir hambatan (confidence to construct a future and deal with career barriers) merupakan suatu tugas perkembangan karier yang spesifik dan mewakili sumber dan strategi adaptabilitas umum yang digunakan seseorang untuk mengatur tugas-tugas penting, transisi dan pengalaman-pengalaman trauma yang mereka miliki seiring proses perkembangan yang terdiri atas $\mathrm{ABC}$, attitudes (sikap-sikap), beliefs (nilai-nilai) dan competencies (kompetensi), dimana ketiga hal tersebut membentuk perilaku adaptasi (Savickas \& Porfeli, 2012).

Inovasi selanjutnya dilakukan oleh Development of two additional Icelandic scales yang menambahkan dua dimensi adaptabilitas karier yaitu kerjasama dan kontribusi (Einarsdöttir et al., 2015) yang telah diujicobakan pada 1.249 mahasiswa universitas di Islandia. Hasilnya adalah skala enam instrumen dengan empat skala internasional yang menjadi perhatian, kontrol, rasa ingin tahu dan keyakinan dan skala tambahan berlabel kerjasama dan kontribusinya, dimana dua skala Icelandic (dimensi kerja sama dan kontribusi) bersifat relasional dalam kehidupan termasuk dalam konstruksi karir kemampuan beradaptasi dan skala enam lebih baik dari skala empat (Guðbjörg Vilhjálmsdóttir, 2017). Hal ini menunjukkan bahwa orang-orang di Islandia mengaktifkan sumber daya di masyarakat saat beradaptasi dengan perubahan karier. Aspek konteks Islandia ini muncul saat Para ahli dalam kelompok fokus menggambarkan bagaimana orang-orang di Islandia beradaptasi dengan perubahan karier dan model enam dimensi ini didukung oleh analisis faktor konfirmatori (Einarsdöttir et al., 2015). Dengan demikian perlu dilakukan penelitian dengan enam dimensi sesuai dengan budaya bangsa Indonesia pada level Perguruan Tinggi.

\section{METODE}

Penelitian dilakukan dengan menggunakan teknik survey kepada 102 orang mahasiswa IAIN Syekh Nurjati Cirebon. Instrumen berpedoman pada enam dimensi adaptabilitas karier mahasiswa sebagaimana dirumuskan oleh Development of two additional Icelandic scales (Einarsdöttir et al., 2015). 


\section{Tabel 1}

Adaptabilitas karier mahasiswa IAIN Syekh Nurjati Cirebon

\begin{tabular}{cccccc}
\hline $\begin{array}{c}\text { Kepedulian } \\
\text { Karier }\end{array}$ & $\begin{array}{c}\text { Pengendalian } \\
\text { Karier }\end{array}$ & $\begin{array}{c}\text { Hasrat } \\
\text { Karier }\end{array}$ & $\begin{array}{c}\text { Kepercayaan } \\
\text { Karier }\end{array}$ & Kerja sama & Konstribusi \\
\hline 18,53 & 18,12 & 17,03 & 18,35 & 19,22 & 17,62 \\
\hline Tinggi & Tinggi & Sedang & Tinggi & Tinggi & Sedang \\
\hline
\end{tabular}

\section{HASIL DAN BAHASAN}

Gambaran umum hasil penelitian dijelaskan dalam tabel 1. Berdasarkan enam aspek adaptabilitas karier, hasil penelitian menunjukkan bahwa pada aspek pertama yaitu kepedulian karier tingkat ketercapaiannya baru $18.53 \%$ berada pada kategori tinggi, pada aspek kedua yaitu pengendalian karier tingkat ketercapaiannya yaitu $18.12 \%$ berada pada kategori tinggi, pada aspek ketiga yaitu hasrat karier tingkat ketercapaiannya yaitu $17.03 \%$ berada pada kategori sedang, pada aspek keempat kepercayaan karier tingkat ketercapaiannya yaitu $18.35 \%$ berada pada kategori tinggi, pada aspek kelima kerjasama tingkat ketercapaiannya yaitu $19.22 \%$ berada pada kategori tinggi dan aspek keenam kontribusi tingkat ketercapaiannya yaitu $17.62 \%$ berada pada kategori sedang.

Adaptabilitas karier sangat penting ditingkatkan guna mempercepat proses penyesuaian terhadap aturan, rekan dan lingkungan kerja yang baru (Savickas, 2013). Menurut Savickas (2013) jika seseorang kurang memiliki adaptabilitas karier, maka orang tersebut menjadi apatis, tidak mampu memutuskan, tidak realistis, dan menahan diri untuk pencapaian kariernya. Adaptabilitas karier memiliki hubungan dengan pembentukan identitas vokasi, di mana lulusan yang mampu beradaptasi dapat memiliki berbagai keterampilan tambahan dan membuatnya lebih dinamis dalam pemilihan bidang pekerjaan (Savickas \& Porfeli, 2012). Dengan demikian, adaptabilitas karier diperlukan untuk menghadapi berbagai konsekuensi memasuki era industri 4.0.

Adapabilitas karier dengan enam dimensi yaitu: kepedulian karier, pengendalian, hasrat, kepercayaan, kerjasama dan kontribusi. Dimensi pertama dari adaptabilitas karier adalah kepedulian terhadap karier (career concern) yakni menyadari pentingnya karir (Aware), terlibat dalam kegiatan berkaitan dengan karier (Involved), dan mempersiapkan perencanan karier di masa depan (Preparing). Mahasiswa dengan masuknya era industri 4.0 yang penuh lompatan luar biasa, menyadari pentingnya karier bagi kehidupan masa depannya yang tidak mudah untuk dijalani tanpa kerja keras dan sungguh-sungguh. Kesungguhan mereka bisa diawali dengan melibatkan diri dalam karier dengan 
merencanakan kariernya. Pekerjaan apa yang mau mereka tekuni untuk bisa menghasilkan sesuatu yang diharapkannya, dirancang sejak dini dengan kesiapan belajar mencari pengalaman.

Lebih jelas, hasil penelitian dengan menggunakan 6 dimensi tersebut dideskripsikan sebagai berikut; Pertama adalah dimensi mengenai kepedulian karier (career concern) dengan tingkat ketercapaiannya $18.53 \%$ berada pada kategori tinggi, merupakan dimensi pertama dan penting dari adaptabilitas karier mahasiswa. Kepedulian karier berkaitan dengan kepercayaan setiap individu dalam mencapai cita-citanya. Seseorang yang memiliki kepedulian karier akan mempunyai pandangan lebih jelas dan mempunyai keyakinan akan masa depannya dalam mewujudkan perencanaan karier. Jika seseorang yang tidak memiliki kepedulian karier akan cenderung menghindari tanggung jawab mewujudkan cita-citanya, bahkan tidak mengambil keputusan dalam kariernya.

Dimensi kedua dari adaptabilitas karier adalah pengendalian (career concern) yang tingkat ketercapaiannya yaitu $18.12 \%$ berada pada kategori tinggi, dalam hal ini mahasiswa menunjukkan tegas dalam mengambil keputusan (Assertive), disiplin (Disciplined) dan memiliki kemauan keras (Wilful). Dimensi ini dimaksudkan bahwa seseorang percaya bahwa mereka bertanggung jawab untuk membangun karier mereka sendiri. Jika seorang mahasiswa yakin akan pengendalian karier yang dimilikinya, remaja akan lebih yakin dalam membuat pilihan-pilihan kariernya. Kurangnya pengendalian karier remaja menyebabkan remaja menjadi bingung dalam penetapan karier yang menyebabkan penundaan dalam menyelesaikan setiap tugas. Akibat dari kebingunan ini akan berpengaruh juga terhadap penyelelesaian studinya, sederhananya; pikiran mereka mempercepat studi juga toh belum jelas pilihan kariernya.

Dimensi ketiga dari adaptabilitas karier adalah hasrat ingin tahu terhadap karier (career curiousity) dengan tingkat ketercapaiannya yaitu $17.03 \%$ berada pada kategori sedang, dengan indikasi mahasiswa melakukan uji coba (Eksperimenting), berani mengambil resiko (Risk Tiking), dan menyelidiki (Inquiring). Dimensi inilah yang akan menimbulkan mahasiswa mencari banyak informasi tentang karier yang diminati. Seseorang yang memiliki rasa keingintahuan yang tinggi mengenai karier, mereka akan memiliki sikap yang antusias dalam pemilihan kariernya. Seseorang yang memiliki rasa keiingintahuan akan kariernya rendah, maka ia akan menjadi tidak realistis dalam menghadapi kehidupan kerjanya. 
Dimensi keempat dari adaptabilitas karier adalah kepercayaan diri terhadap karier (confidence) dengan tingkat ketercapaiannya yaitu $18.35 \%$ berada pada kategori tinggi dengan indikator Gigih (Persistent), berjuang keras (Striving) dan Rajin (Industrious). Kepercayaan diri terhadap karier (career confidence), di mana setiap orang membutuhkan keyakinan dan kepercayaan diri dalam mengambil keputusan karier. Keyakinan mahasiswa merupakan kemampuan pemecahan masalah karier pada mahasiswa sekaligus sebagai petunjuk kemampuan memenuhi kebutuhan karier mereka. Keyakinan karier muncul dari pemecahan masalah yang dihadapi dalam kehidupan sehari-hari seperti di rumah atau di tempat kuliah. Modal percaya diri ini menjadi spirit bagi mahasiswa untuk terus belajar, mengembangkan potensi dan kompetensi diri sehingga lebih siap menyongsong kesuksesan masa depannya.

Dimensi Kelima dari adaptabilitas karier adalah kerja sama (cooperation) dengan tingkat ketercapaiannya yaitu $19.22 \%$ berada pada kategori tinggi yakni mahasiswa mulai membangun jaringan (Networking), memimpin (leading) dan memahami (understanding). Kerjasama merupakan hal yang sangat penting dan diperlukan dalam kelangsungan hidup manusia. Tanpa adanya kerjasama tidak akan ada keluarga, organisasi, ataupun sekolah, khusunya tidak akan ada proses pembelajaran di sekolah. Lebih jauh pendapat Anita Lie dapat diartikan, bahwa tanpa adanya kerjasama siswa, maka proses pembelajaran di sekolah tidak akan berjalan dengan baik dan akhirnya tujuan pembelajaran tidak akan tercapai. Melihat pentingnya kerjasama siswa dalam pembelajaran di kelas maka sikap ini harus dikembangkan. Terlibat aktif dalam bekerja kelompok, Kesediaan melakukan tugas sesuai kesepakatan, Bersedia membantu orang lain dalam satu kelompok yang mengalami kesulitan, Menghargai hasil kerja anggota kelompok/team work.

Dimensi keenam dari adaptabilitas karier adalah kontribusi (contribution) dengan kontribusi tingkat ketercapaiannya yaitu $17.62 \%$ berada pada kategori sedang. yakni memiliki tujuan (Purposeful), mampu mengarahkan (Directed) dan Aktif (Active). Mahasiswa memiliki tujuan dalam kariernya berarti sudah memiliki orientasi masa depan yang mesti dipersiapkan dengan baik. Memiliki kemampuan mengarahkan pada karier tertentu sehingga bisa focus pada realitas apa yang dicita-citakannya. Mahasiswa aktif meningkatkan kompetesnsinya dengan kesadaran bahwa memasuki era industri 4.0 membutuhkan kreatifitas dan daya saing yang tinggi. Realitas era industri 4.0 yang luar 
biasa, dibutuhkan adaptabilitas karier yang tinggi, dengan harapan kesuksesan karier mereka di masa depan menjadi kenyataan.

\section{KESIMPULAN}

Berdasarkan hasil penelitian ini, disimpulkan bahwa adaptabilitas karier pada mahasiswa angkatan 2018/2019 IAIN Syekh Nurjati Cirebon dinyatakan tinggi karena mahasiswa memiliki kepedulian mengenai karier mereka, mencari informasi mengenai karier yang diminati, tidak ragu dalam pemilihan karier dan memiliki tanggung jawab dalam menentukan karier. Dimensi kerjasama merupakan aspek yang paling tinggi dari semua aspek dimensi pada adaptabilitas karier. Dengan demikian implikasi pada era industri 4.0, mahasiswa memiliki kesiapan untuk bisa beradaptasi dalam kondisi apapun yang menjadi konskuensi logis kemajuan era industri 4.0.

\section{DAFTAR RUJUKAN}

Douglass, R. P., \& Duffy, R. D. (2015). Calling and career adaptability among undergraduate students. Journal of Vocational Behavior, 86(1), 58-65. DOI: 10.1016/j.jvb.2014.11.003

Einarsdóttir, S., Vilhjálmsdóttir, G., Smáradóttir, S. B., \& Kjartansdóttir, G. B. (2015). A culture-sensitive approach in the development of the career adapt-abilities scale in Iceland: Theoretical and operational considerations. Journal of Vocational Behavior, 89(1), 172-181. DOI: 10.1016/j.jvb.2015.06.006.

Guðbjörg Vilhjálmsdóttir, (2017) The Importance of Group Norms in Interpreting Results of Career Adaptability Measures, Department of Career Guidance and Counselling, University of Iceland, Reykjavík, Iceland, DOI: 10.1007/978-3-319-66954-0_22.

Gunawan, W. (2013). Pengaruh Sumber-Sumber Efikasi Diri Dan Efikasi Diri Pengambilan Keputusan Karier Terhadap Adaptabilitas Karier Remaja. (Unpublished master's thesis) Universitas Indonesia, Jakarta, Indonesia.

Irianto, K. (2014). Epidemiologi Penyakit Menular dan Tidak Menular Panduan Klinis. Bandung: Alfabeta.

Kagermann, H., Lukas, W.D., \& Wahlster, W. (2013). Final report: Recommendations for implementing the strategic initiative INDUSTRIE 4.0. Frankfrut: Industrie 4.0 Working Group.

Lee, E. A. (2008). Cyber Physical Systems: Design Challenges. 2008 11th IEEE International Symposium on Object and Component-Oriented Real-Time Distributed Computing (ISORC). DOI:10.1109/isorc.2008.25

Lent, R. W., \& Brown, S. D. (2006). Integrating person and situation perspectives on work satisfaction: A social-cognitive view. Journal of Vocational Behavior, 69(1), 236-247.

Pratzner, F. C., Ashley, W. L. (1984). Occupational adaptability and transferable skills: Preparing today's adults for tomorrow's education. Yearbook of the American Vocational Association. Arlington, TX: American Vocational Association. 
Savickas, M. L. (1997). Adaptability: An integrative construct for life-span, life-space theory. Career Development Quarterly, 45(1), 247-259.

Savickas, M. L. (2013). Career construction theory and practice. In R. W. Lent, \& S. D. Brown (Eds.), Career development and counseling: Putting theory and research to work (pp. 147-183) (2nd ed.). Hoboken, New Jersey: John Wiley \& Sons.

Savickas, M. L., \& Porfeli, E. J. (2011). Revision of the career maturity inventory: The adaptability form. Journal of Career Assessment, 19(1), 355-374.

Savickas, M. L., \& Porfeli, E. J. (2012). Career adapt-abilities scale: Construction, reliability, and measurement equivalence across 13 countries. Journal of Vocational Behavior, 80(1), 661-673. DOI: 10.1016/j.jvb.2012.01.011.

Schlechtendahl, J., Keinert, M., Kretschmer, F., Lechler, A., \& Verl, A. (2015). Making existing production systems Industry 4.0-ready. Production Engineering, 9(1), 143148.

Seligman, M. (1994). What you can change and what you can't. New York: Knopf.

Suwardana, H. (2017). Revolusi Industri 4. 0 Berbasis Revolusi Mental. JATI UNIK, 1(2), $1-10$.

Yousefi, Z., Abedi, M., Baghban, I., Eatemadi, O., \& Abedi, A. (2011). Personal and Situational Variables, and Career Concerns: Predicting Career Adaptability in Young Adults. The Spanish Journal of Psychology, 14(01), 263271. DOI:10.5209/rev_sjop.2011.v14.n1.23 